\title{
Stream channel changes as a result of sudden sediment release due to check dam lowering (Polish Carpathians)
}

\author{
Joanna Korpak ${ }^{1}$ (D) Anna Lenar-Matyas ${ }^{1}$
}

Received: 30 August 2018 / Accepted: 3 July 2019 / Published online: 12 July 2019

(c) The Author(s) 2019

\begin{abstract}
Channel response to dam removal is still poorly understood, as there is a lack of monitoring data. A small dam in the gravel bed Krzczonówka Stream was lowered in 2014 as the first in the Polish Carpathians. The paper describes the direction and magnitude of channel changes after the check dam lowering against the backdrop of slow changes in the riverbed occurring over a period of several decades. Geomorphologic mapping and geodetic measurements started in 2013 and were repeated in 2014. Archived cartographic sources were used to identify channel morphology in the past. After the studied check dam had been partially lowered, a flood occurred and caused movement of sediment from the reservoir into the channel downstream. Debris filled pools and artificial riffles were created in 2013-the largest deposition occurred just below the dam. The channel width also increased in this area. The channel reach upstream from the dam was incised. Additional gravel supply is limited because of a sequence of drop structures just upstream of the studied reach. Long-term channel evolution after dam lowering depends on flood events and the availability of material for fluvial transport.
\end{abstract}

Keywords Channel morphology changes $\cdot$ Stream channel adjustment $\cdot$ Stream channel restoration $\cdot$ Dam removal $\cdot$ Polish Carpathian Mountains

\section{Introduction}

The problem faced in Carpathian rivers in Poland, as is the case with many mountain rivers in the world, is the presentday shortage of material for fluvial transport (Park 1977; Richards and Lane 1997; Liébault and Piégay 2001).

One of the main reasons for the decrease in the amount of material available for fluvial transport in streams is the widespread use of dams of different size (Kondolf et al. 2014). In the Polish Carpathian Mountains, many small check dams were built, mostly in the years 1930-1970. Today, many of them do not serve their intended purpose, as their reservoirs are completely filled with sediment (Ratomski 1991). Check dams break stream continuity, store bedload, and this starves the stream downstream of material (Petts and Gurnell 2005). Underloaded rivers experience erosion and low geomorphologic diversity of channel landforms (Korpak 2018).

Joanna Korpak

jkorpak@iigw.pl

1 Department of Engineering and Water Management, Cracow University of Technology, Warszawska 24, 31-155 Cracow, Poland
Water quality worsens (Jaske and Goebel 1967; Doyle et al. 2003), as does the general state of the ecosystem (Ward and Stanford 1995). Deepened and steep channel reaches create the threat of flooding for valley areas downstream of them (Wyżga and Radecki-Pawlik 2011).

One way of restoring a dammed river is dam lowering or removal. Such solutions are frequently used in the US (Gleick et al. 2009). River channels regain transport continuity, but may experience a number of geomorphologic and ecological problems such as increased sedimentation, changes in water quality, altered nutrient loads, and harm to living organisms (Wohl and Cenderelli 2000; Stanley and Doyle 2002; Hart et al. 2004; Rathburn and Wohl 2004). Excess deposition downstream of a removed dam may reduce channel capacity and generate flood risk (Bednarek 2001; Randle 2004). On the other hand, the reach upstream of a removed dam experiences base level lowering and consequently greater erosion, which may cause social and economic problems in the form of loss of land and undercutting of bridges or other technical structures (Amos 2008).

Research has shown that the scale of channel change due to dam removal may vary (Grant 2001). To predict changes and understand their mechanisms, multiple monitoring 
studies are needed in channels with different local conditions (Pizzuto 2002). Yet most dam lowering projects are not continuously monitored (Stewart and Grant 2005), which explains the large number of questions surrounding this solution. One question concerns transport of the sediment wave in translation or dispersion mode (Madej and Ozaki 1996; Pizzuto 2002) as well as the rate of transport and deposition (Shuman 1995; Doyle et al. 2003). The key problem is the direction and rate of change in the channel reach upstream of the dam following its removal and base level lowering (Simon 1989; Simon and Hupp 1992). In addition, it is not known how long a given river needs to regain hydrodynamic equilibrium following dam removal (Burroughs et al. 2009).

The first partial lowering of a check dam in the Polish Carpathians occurred in 2014 on Krzczonówka stream. The restoration works included, in addition to dam lowering, the erection of artificial riffles along a stream section from the check dam to the stream mouth (Fig. 1b). As reconstruction work was being performed on the dam, and after it had been already partially lowered, a rainfall event occurred, which then led to a flood event. This event created a very unique opportunity to observe the response of the stream to the intervention in question.

The paper describes initial changes in stream channel morphology, which occurred as a result of check dam lowering against the backdrop of stream channel change over

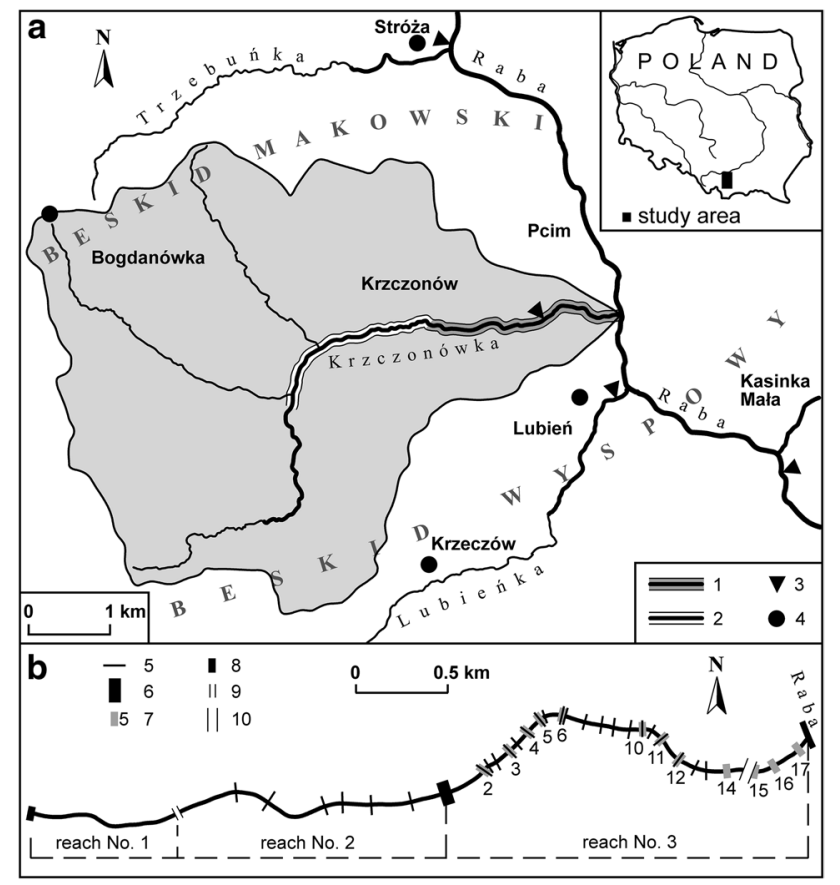

Fig. 1 Location of study area: a Krzczonówka River catchment, b studied channel segment; 1-studied channel segment, 2-channel segment regulated with drop structures, 3-gauging site, 4-precipitation station, 5-cross section, 6-check dam, 7-artificial riffle and its number, 8-drop structure, 9-footbridge, 10-bridge a period lasting several decades. As the Krzczonówka dam is the first dam lowered in Poland, the main purpose of the paper is to determine whether the direction and scale of changes in the Krzczonówka channel are similar to changes in channels in other regions that have been subjected to such an intervention. The paper also aims to show the need to study the evolution of a given reach over a longer period of time to better understand local conditions, anticipate possible channel changes and related problems, and choose the best possible restoration strategy.

\section{Study area}

Krzczonówka Stream is located in the Western Carpathians in the catchment of the Raba River (Fig. 1). The stream separates the Beskid Wyspowy Mountains from the Beskid Makowski Mountains, both belonging to Flysch Western Carpathian Mountains. The entire catchment is formed of sedimentary rocks, mainly sandstone and shale of high resistance (layers of the Magura series). The area is characterized by very small tectonic activity. Rates of river downcutting associated with neotectonic uplift are estimated at $0.2-2.0 \mathrm{~mm} /$ year in the last 15,000 years. The recent significant acceleration of the river downcutting is related to human activity (Zuchiewicz 1998). The surface area of the Krzczonówka stream catchment is $92.2 \mathrm{~km}^{2}$; elevations range from $329 \mathrm{~m}$ a.s.l. at the mouth to $866 \mathrm{~m}$ a.s.l. at its highest point. The channel is $17 \mathrm{~km}$ in length. The channel gradient is 0.024 and average channel width is $14 \mathrm{~m}$. The average annual precipitation for the period 1961-2000 at the Lubień precipitation station, which lies in a neighboring catchment, was $1050 \mathrm{~mm}$ (Paszkiewicz 2009). Average annual discharge for the period 1961-2000 was $1.615 \mathrm{~m}^{3} / \mathrm{s}$ (Nachlik 2006). The studied stream is characterized by great variability of discharge.

A comprehensive research study covered the downstream part of the stream channel-length of $4.6 \mathrm{~km}$. This is a stream reach that experiences the impact of a small dam located at $2.25 \mathrm{~km}$ measured from the mouth (Fig. 1b). The Krzczonów gauging site is located downstream from the dam at $2.0 \mathrm{~km}$. Most of the stream debris may be classified as gravel; medium grain size in the studied reach is $0.04 \mathrm{~m}$ (Project No. 214004-00 2011).

Substantial rainfall occurred in southern Poland in May of 2014, after the dam had already been partially lowered and did not constitute a barrier to sediment transport. The highest discharge at the Krzczonów gauging site was observed overnight on May 15 into May 16, with a value of about $133 \mathrm{~m}^{3} / \mathrm{s}$ (probability 5\%). This value was calculated based on readings at the nearest gauging sites in adjacent catchments (gauges: Stróża and Kasinka Mała on the Raba, Fig. 1a, Table 1). The Krzczonów gauge provided a reading 
Table 1 Maximum stream discharge and precipitation during a flood in May 2014 (data from the Institute of Meteorology and Water Management)

\begin{tabular}{|c|c|c|c|c|c|c|c|}
\hline \multirow[t]{2}{*}{$\begin{array}{l}\text { Gauging site or pre- } \\
\text { cipitation station }\end{array}$} & \multirow[t]{2}{*}{ Stream or river } & \multirow[t]{2}{*}{$\begin{array}{l}\text { Catchment } \\
\text { size }\left(\mathrm{km}^{2}\right)\end{array}$} & \multirow[t]{2}{*}{$\begin{array}{l}\text { Maximum discharge on } \\
\text { May } 16,2014\left(\mathrm{~m}^{3} / \mathrm{s}\right)\end{array}$} & \multirow[t]{2}{*}{$\begin{array}{l}\text { Probability of } \\
\text { occurrence }\end{array}$} & \multicolumn{3}{|c|}{$\begin{array}{l}\text { Precipitation on May 14-16, } 2014 \\
\text { (mm/day) }\end{array}$} \\
\hline & & & & & May 14 & May 15 & May 16 \\
\hline Kasinka Mała & Raba & 353.3 & 243 & Q13\% & - & - & - \\
\hline Lubień & Lubieńka & 47.8 & 51.9 & Q14\% & 34.8 & 117.5 & 41.0 \\
\hline Krzczonów & Krzczonówka & 92.2 & 254 & $\mathrm{Q} 0.2 \%$ & - & - & - \\
\hline Stróża & Raba & 644.1 & 676 & Q2\% & 32.0 & 87.2 & 54.9 \\
\hline Bogdanówka & Krzczonówka & 92.2 & - & - & 41.0 & 125.1 & 41.7 \\
\hline Krzeczów & Lubieńka & 47.8 & - & - & 23.3 & 94.6 & 33.8 \\
\hline
\end{tabular}

of $254 \mathrm{~m}^{3} / \mathrm{s}$ (probability $0.2 \%$ ), which appears to be elevated compared with values (probability 4-14\%) obtained in adjacent catchments. Readings from area precipitation stations show that the precipitation occurring during this event was distributed evenly across the region (Fig. 1a, Table 1). The vast amount of material carried away by floodwaters from the dam reservoir to the reach downstream was most likely the reason for the elevated water levels measured at the Krzczonów gauging site.

\section{Methods}

\section{Collection and analysis of field data}

To show changes in channel morphology after the restoration works, the channel was studied in 2013, before dam lowering but after erection of artificial riffles, and in 2014, after dam lowering and a flood event. Both geodetic measurements and geomorphologic mapping were performed.

Geodetic measurements, which included cross-sectional analysis, were performed using a GPS Topcon Hiper II receiver set. A total of 20 cross sections were examined downstream of the dam and 6 upstream of it (Fig. 1b). Cross sections were situated on crests of artificial riffles and downstream from them. It proved impossible to establish reliable cross sections above riffle no. 2 , because the section between the check dam and riffle no. 2 was quickly extracted after flood to dig out a buried water level gauge. Cross sections were also not made below riffle no. 12, because the lower section of the stream experienced changes in morphology in 2014 due to a flood on the Raba River. Raba then altered its course and forged forward into the valley of Krzczonówka stream increasing its water levels.

An attempt was made to estimate the volume of debris accumulated in reaches between riffles. Sediment volume was computed by dividing average net change in channel area measured from cross sections of adjacent riffles by the channel length between the given cross sections (Madej and
Ozaki 1996). Net change in streambed cross-sectional area was defined as the difference between fill and scour in the streambed between surveys in 2013 and 2014. This calculation of debris volume must be treated as an estimate and may be used to show certain tendencies that are associated with riffle effects on deposition.

Geomorphologic surveys of the studied channel were performed using a method developed specifically for Carpathian rivers (Kamykowska et al. 1999) and tested multiple times in the Carpathians as well as in other mountain areas (Kaszowski and Krzemień 1977; Chełmicki and Krzemień 1999; Korpak 2007). The channel was divided into three reaches based on the general pattern of the watercourse and distribution of channel forms (Fig. 1b):

- Reach no. 1 -from the first drop structure (which initiates a series of drop structures) to the footbridge, with a length of $0.83 \mathrm{~km}$.

- Reach no. 2-from the footbridge to the check dam, with a length of $1.52 \mathrm{~km}$.

- Reach no. 3-from the check dam to the mouth, with a length of $2.25 \mathrm{~km}$.

The reaches were described using a special table on the basis of many different quantitative and qualitative characteristics. Six of them were selected for further analysis of channel reaches morphology:

1. number of bars per $\mathrm{km}$,

2. area of bars (product of their length and width) in $\mathrm{m}^{2}$ per $\mathrm{km}$,

3. braiding ratio (number of central bars per $\mathrm{km}$ ),

4. number of cutbanks per $\mathrm{km}$,

5. area of cutbanks (product of their length and height) in $\mathrm{m}^{2}$ per $\mathrm{km}$,

6. number of rocky steps per $\mathrm{km}$.

The length, width, and height of fluvial forms were measured in the field with a tape. 


\section{Analysis of cartographic sources and archived materials}

General changes in channel course and land cover patterns were analyzed using a topographic map from 1879 (Austrian map, 1:75,000) as well as aerial photographs taken in 1963 (1:19,000), 1977 (1:16,000), and 1993 (1:30,000), and orthophotomaps from 2006 to 2016. Prior to comparative analysis, all materials were brought to a uniform scale of 1:10,000 and a coordinate system known as PUWG1992. Boundaries of the active stream channel were then digitized from georeferenced and ortho-rectified sources using OCAD software. An active stream channel was defined as a wetted low-flow channel and gravel bars without vegetation or with patches of young vegetation (Hajdukiewicz and Wyżga 2019). The area of active channel was measured for the same three reaches determined during geomorphologic surveys. Then for each reach, the channel width was calculated by dividing the area of active channel reach by its length. Moreover, the minimum and maximum widths of channel reaches were measured perpendicular to the active channel axis. Measurement error resulting from the difficulty in determining where precisely the water's edge is located due to streambanks concealed by trees or shadows cast by trees was estimated to be $0-5 \mathrm{~m}$.

Archived materials on river regulation projects obtained from the Kraków Regional Water Management Authority, as well as project of renovation of the Krzczonówka stream obtained from Ab Ovo Association were used to identify engineering works performed on the studied stream in the past.

\section{Results}

\section{Evolution of the channel in the past}

In 1879 , the studied reach was alluvial with a wandering channel pattern despite the presence of water mills, which involved local channel deepening and the installation of structures to manage the flow of water (Fig. 2).

In the years 1935-1951, a $7 \mathrm{~m}$ high concrete and stone check dam at $2.25 \mathrm{~km}$ was built. Its main purpose was to prevent the erosion of the channel bottom, which caused the process of sliding on high, steep slopes present in most cases along the right stream bank. Once completed, the dam interrupted sediment transfer downstream resulting in sediment deposition upstream and erosion downstream with associated channel morphology (Korpak 2007).

In the 1960s and 1970s, the studied check dam reservoir still trapped large quantities of sediment, and the channel upstream from the dam was alluvial, with width exceeding $100 \mathrm{~m}$ at some locations (Figs. 3b, 4). The channel downstream from the dam was narrowed and deepened (Figs. 3e, 4). Erosion threatened the stability of roads situated along the banks. To protect roads, an array of longitudinal hydraulic structures such as groins, longitudinal dams, and embankments were built in the late 1950s and early 1960s.

In the 1980s, the installation of concrete drop structures upstream of the studied channel section was begun. Additional drop structures were added along the river up to the $4.6 \mathrm{~km}$ from the mouth (Fig. 1a). This project substantially impacted further development of the channel. Material carried by the stream became trapped between drop structures, which then starved the stream channel downstream of material.

In 1993, channel regulation with drop structures continued and was expected to include the last reach with a length of about $3.4 \mathrm{~km}$. Hence, the channel upstream of the dam was still experiencing debris supply. It was much more
Fig. 2 Studied segment of the Krzczonówka stream channel in 1879 (dotted areas adjacent to the stream denote bars): 1 -location of water mills and a water sawmill, 2-present location of check dam, 3-present location of concrete drop structure

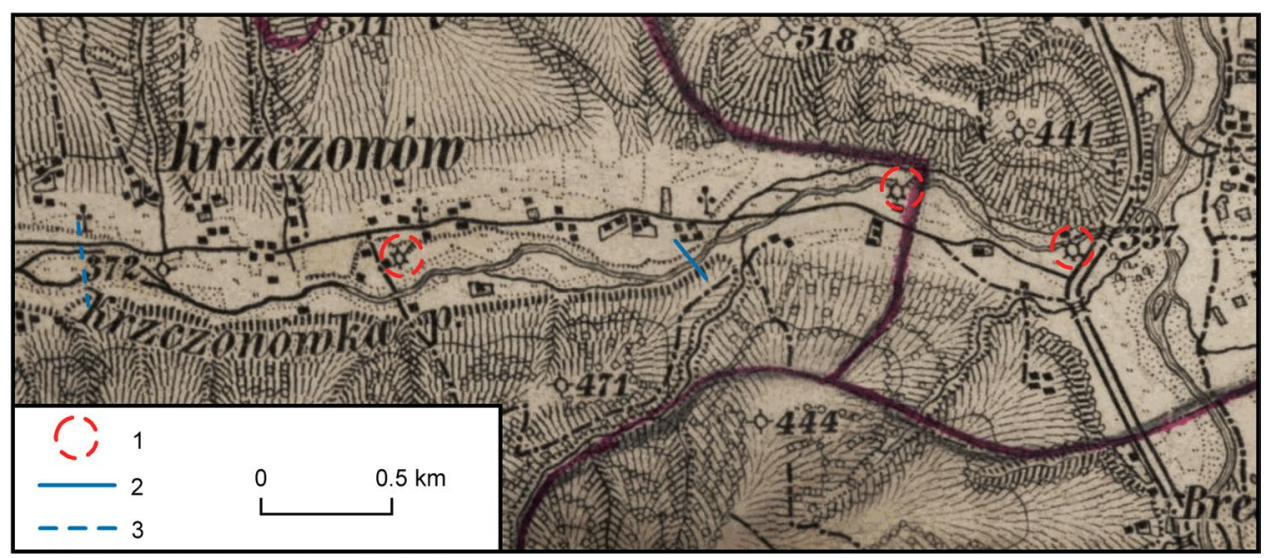



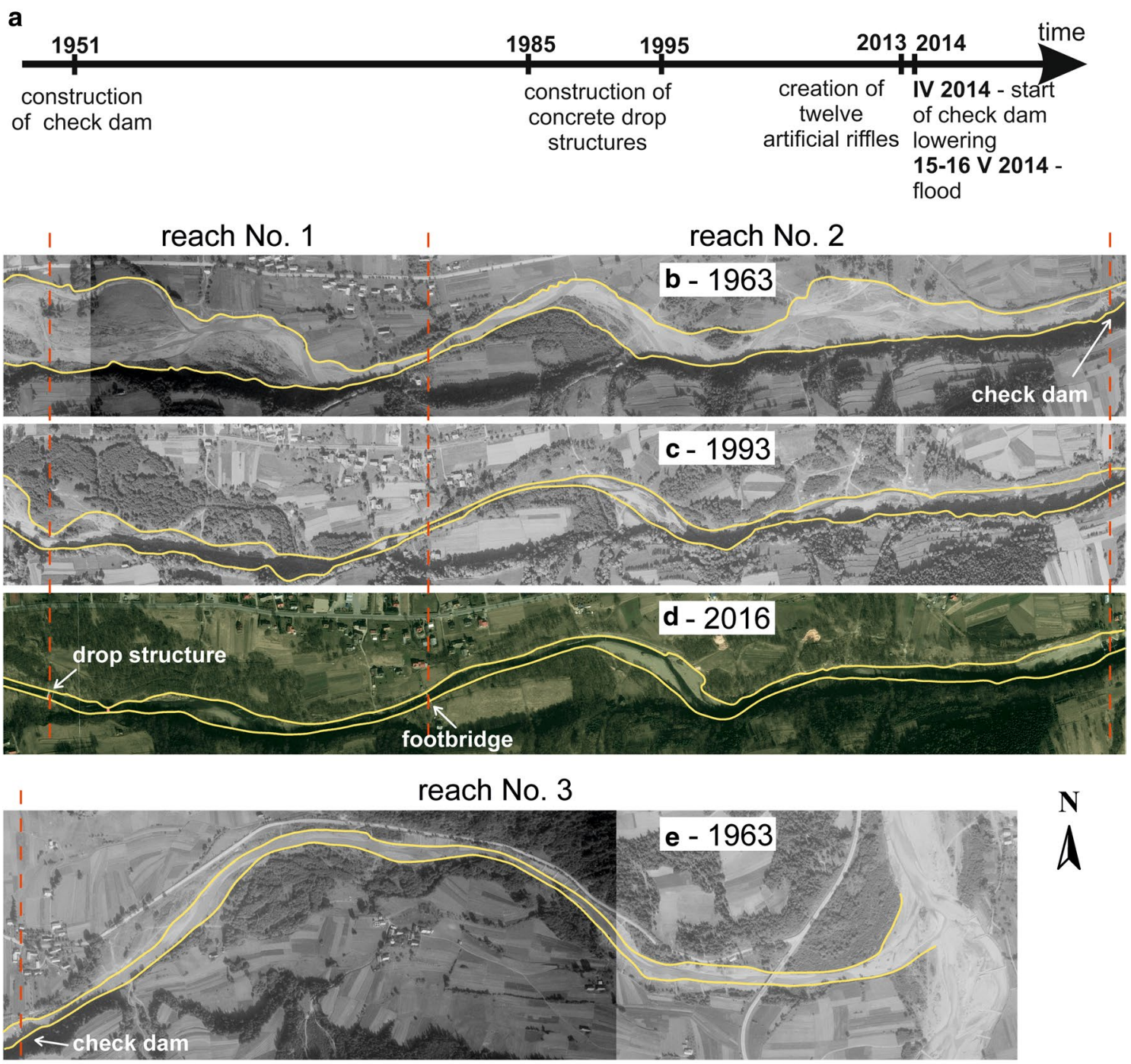

\section{$\mathbf{N}$}
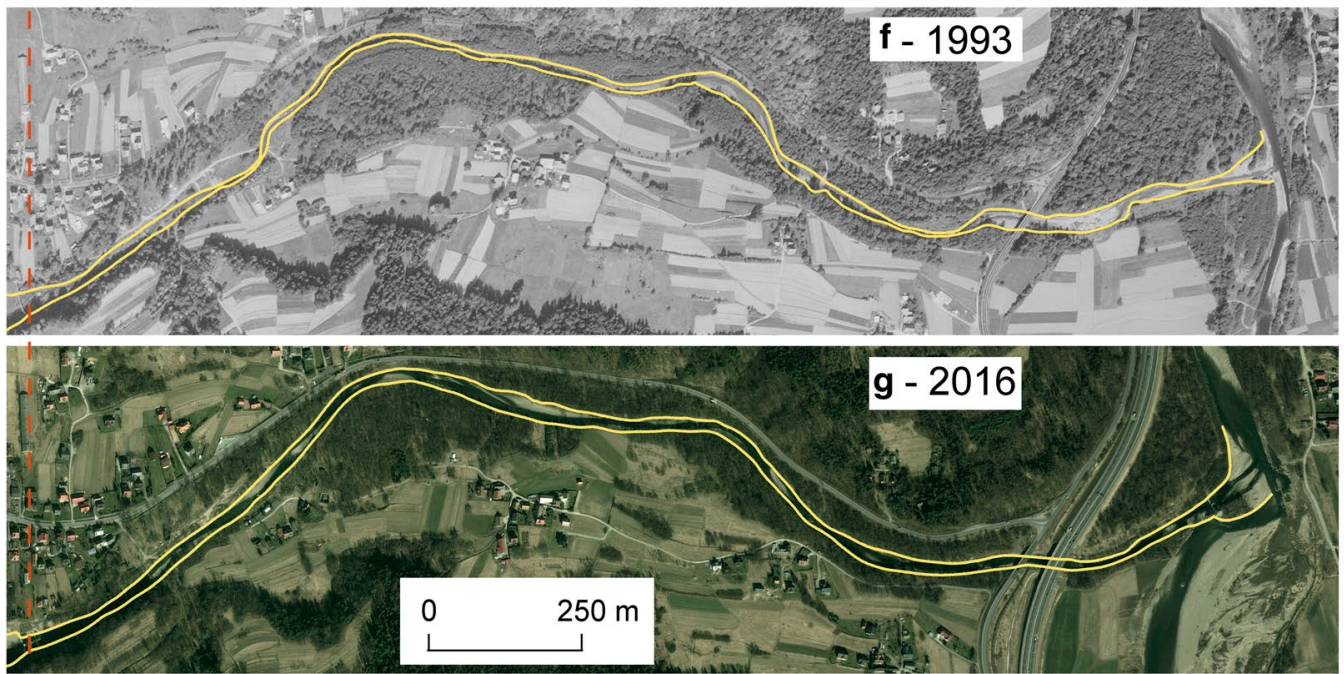

Fig. 3 Changes in the morphology of the Krzczonówka stream channel along three studied reaches: a timeline graph with stages of engineering works, b-d channel changes from the first drop structure to the footbridge (reach no. 1) and from the footbridge to the check dam (reach no. 2), $\mathbf{e}-\mathbf{g}$ channel changes from the check dam to the mouth; the yellow line indicates the boundary of the active channel 

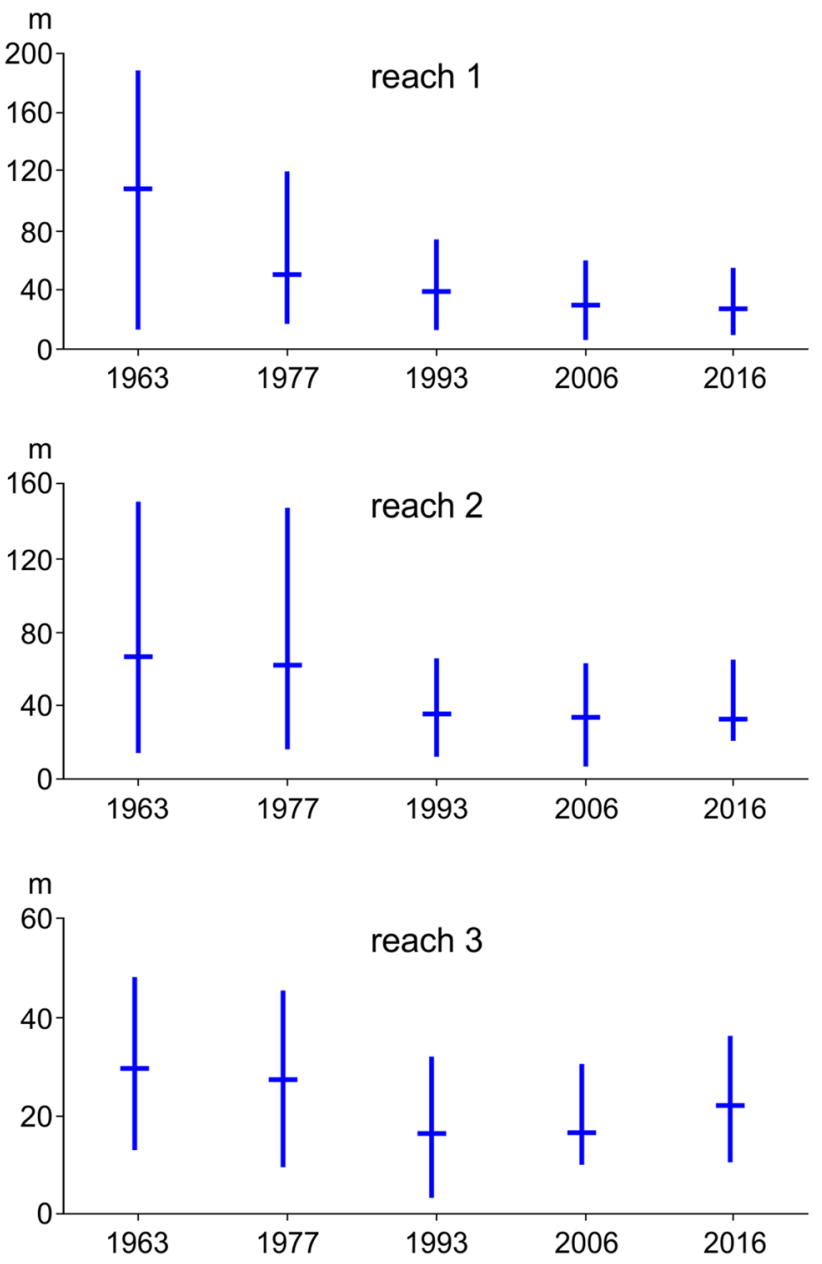

Fig. 4 Changes in the maximum, mean and minimum width of the active channel in three studied reaches of the Krzczonówka stream in the years 1963-2016

narrow than it had been in 1977 (Fig. 4), but still tended to follow a braided pattern in some areas (Fig. 3c).
The renovation of the studied dam occurred in the late 1990s. The reservoir above the dam was already completely filled with sediment. The dam was in very poor technical condition. There were concerns that the selfdestruction of the dam would cause strong erosion in the channel reach upstream from it, which in turn would threaten the stability of recently performed stream regulation using drop structures. Renovation works helped lower the principal chute spillway by $2 \mathrm{~m}$. The dam was re-engineered into a cascade composed of three concrete steps (Fig. 5a).

The Krzczonówka stream channel, both downstream and upstream from the dam, was single threaded and narrow in 2006 (Fig. 4), and in many places, it was cut down to the bedrock. By this time, the period of regulation via drop structures had ended. Hence, the influx of material to the studied reach was very limited.

The width of the Krzczonówka stream channel decreased and became uniform along the entire studied section during the period 1963-2006 due to the interventions performed (Fig. 4). The channel upstream from the dam changed much more than the channel downstream from it. The greatest change occurred during the period 1977-1993 and was driven primarily by the filling of the dam reservoir with sediment and a significant decrease in the supply of material from the channel segment regulated using drop structures. Only in reach no. 1 did the main change in channel width occured earlier-in the period 1963-1977. For unknown reasons, a significant part of the area of the active channel became transformed into a terrace at the time. Drop structures in the upstream reach had not been constructed yet and there does not exist any information on any other regulation work at the time. The most likely reason was channel deepening due to the extraction of debris, but there is no proof of this.

Major changes in the width and morphology of the channel are visible on an orthophoto from 2016 (Figs. 3d, $\mathrm{g}, 4)$. These changes are mainly the result of restoration work.
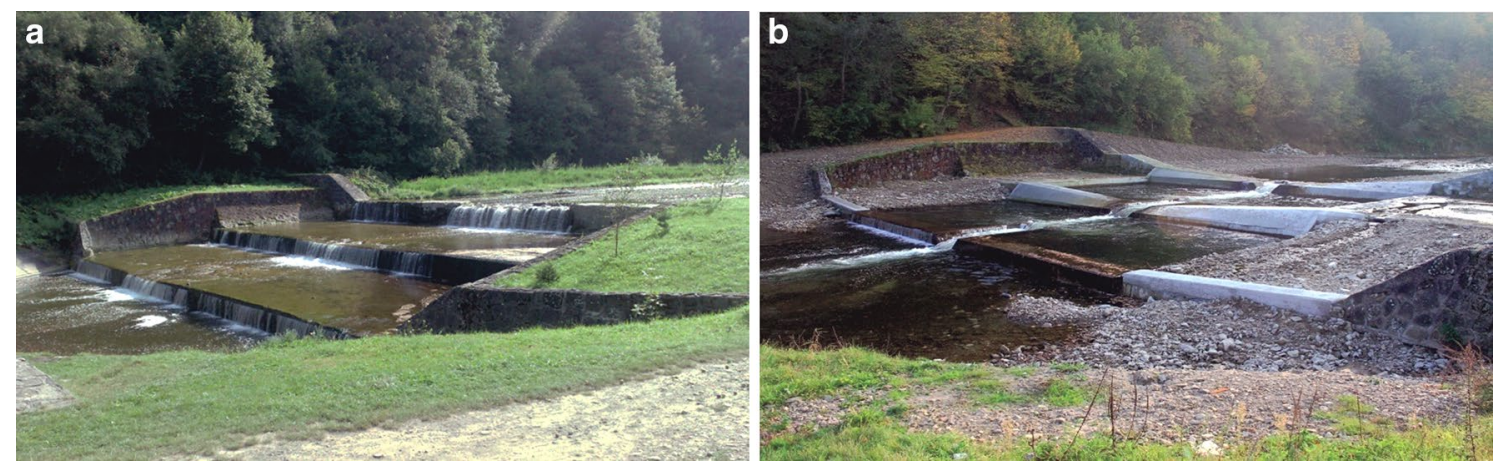

Fig. 5 Results of restoration works in the Krzczonówka stream channel: a check dam prior to lowering, b lowered and modernized check dam 


\section{Changes in the stream channel due to the lowering of the check dam}

In the years 2013-2014, a restoration project was implemented along the Krzczonówka channel segment from the check dam to the mouth. The main goals of the project were to prevent further downcutting downstream from the dam and to restore the continuity of the stream and the opportunity for fish to migrate upstream to their spawning grounds. Twelve artificial riffles about $120 \mathrm{~m}$ apart from each other, with height rangeing from 0.6 to $1.2 \mathrm{~m}$, were created in 2013 to decrease the channel gradient, unit stream power as well as the intensity of erosion. The riffles were made of piled-up broken rocks of a size exceeding the natural grain size. A reconstruction of the check dam was performed in 2014. The highest step of the dam was lowered by $1.8 \mathrm{~m}$, the middle by $0.96 \mathrm{~m}$, and the lowest by $0.37 \mathrm{~m}$. Additionally a trapezoidal notch was made in the central part of every step to provide for the free movement of fish (Fig. 5b).

The results of field observations will be presented in relation to the three channel reaches identified in the course of geomorphologic mapping (Fig. 1b).
In reach no. 1, the number and area of bars nearly did not change and remained small in the period 2013-2014 (Fig. 6). The number and area of cut banks did increase substantially. This reach was also characterized by the largest number of rock steps with a height of about $0.3 \mathrm{~m}$.

The most readily observable change in reach no. 2 is a large increase in the number and area of cut banks (Fig. 6). The number and area of bars decreased. A large part of sediment, especially those found in the reservoir, was eroded and transported downstream. The stream channel bottom here was lowered by as much as $2 \mathrm{~m}$ (Fig. 7a).

Finally, in reach no. 3, the number and area of cut banks increased to some extent, but in comparison with the two other reaches, the effects of bank erosion here were the least important. The most readily observable change in this reach was a large increase in the area of bars and a relatively small increase in their number (Fig. 6). About $38 \%$ of the bars surveyed in 2014 were mid-channel bars, as seen in the increased braiding ratio The large deposition was the effect of an abrupt delivery of debris from the reservoir and a decrease in the channel gradient along this section due to the construction of artificial riffles. Almost all the artificial
Fig. 6 Change in the number and area of channel bed forms in the studied reaches of the Krzczonówka channel in the years 2013-2014: a number of bars per $1 \mathrm{~km}, \mathbf{b}$ area of bars in $\mathrm{m}^{2}$ per $1 \mathrm{~km}$, c braiding ratio, $\mathbf{d}$ number of cut banks per $1 \mathrm{~km}$, e area of cut banks in $\mathrm{m}^{2}$ per $1 \mathrm{~km}$, $\mathbf{f}$ number of rocky steps per $1 \mathrm{~km}$ a

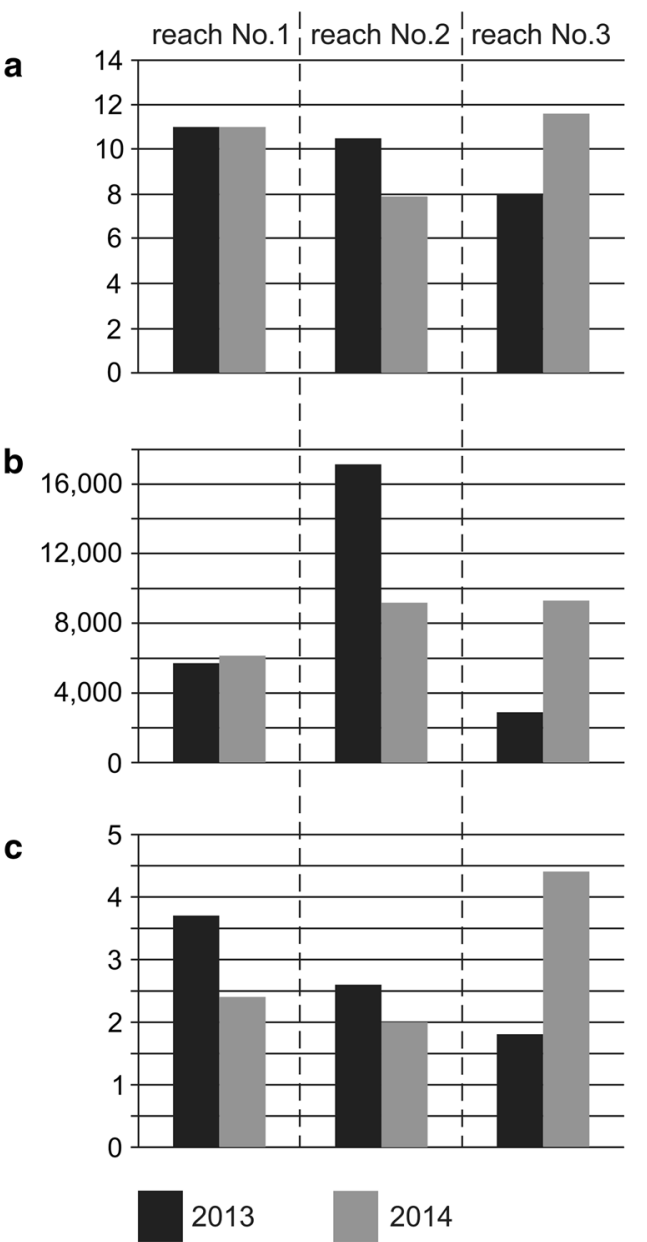

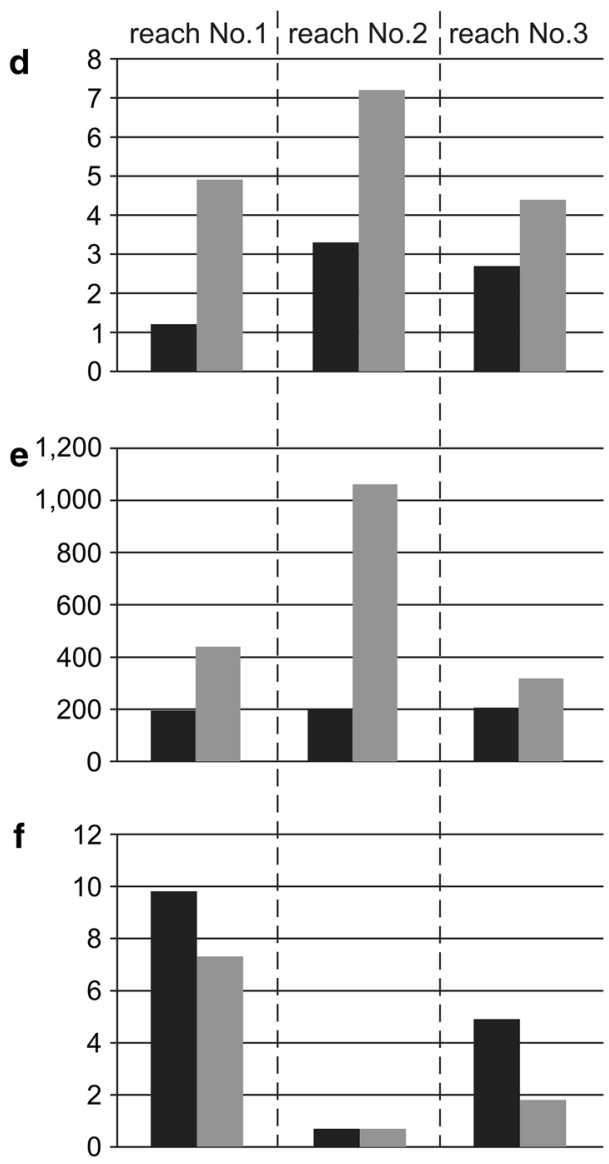


Fig. 7 Changes in the morphology and geometry of the studied channel reaches due to restoration works and flooding: $\mathbf{a}$ in the reach from the footbridge to the check dam, b, $\mathbf{c}$ in the reach from the check dam to the mouth; 1-gravel bar, 2-high gravel bar with vegetation, 3-dry high-water channel, 4-natural riffle, 5-artificial riffle, 6-rip-rap, 7-rocky step, 8-rocky outcrop, 9-cut bank (height 0-2 m), 10 - cut bank (height $>2 \mathrm{~m}$ ), 11 -flow direction, 12-location of cross sections

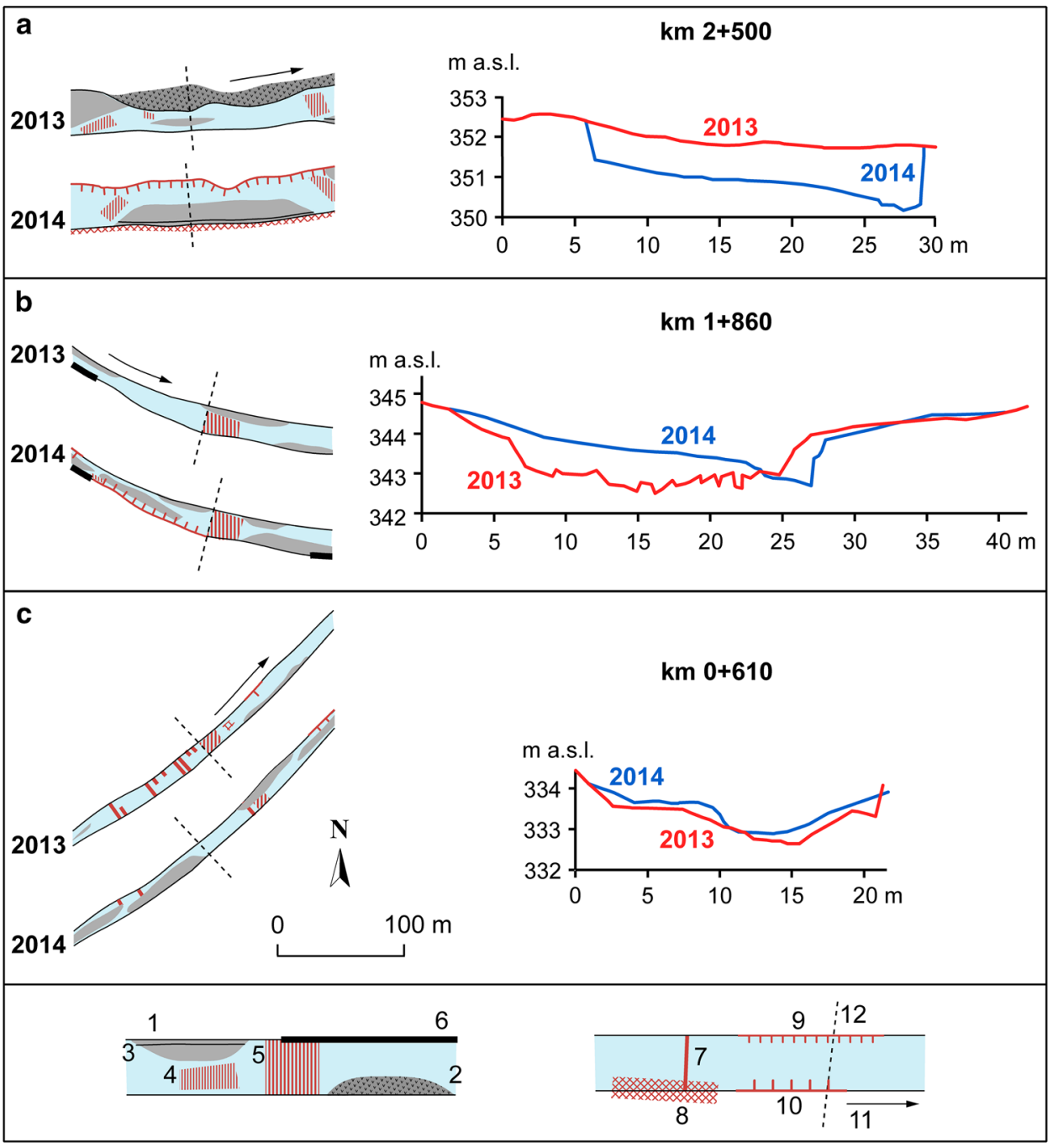

riffles in 2014 were covered with sediment and not visible. The thickness of the layer of deposited material reached values ranging from 0.21 to $0.91 \mathrm{~m}$ and, in general, was largest nearby the dam and decreased in the direction of the stream mouth (Lenar-Matyas et al. 2015, Fig. 7b, c). This trend is also visible in the diagram showing the volume of material and area of bars deposited between riffles 2 and 12 (Fig. 8). Field surveys conducted the day after the studied flood indicated the largest deposition just below the dam before riffle no. 2. However, the cross sections were measured later when this reach had already been dug out. In 2013, small bars occurred usually between riffles 6 and 12 (Fig. 8). After a flood, a large number of bars were noted close to the dam, especially between riffles 5 and 6 due to the small gradient of this river section (Fig. 8). Deposition substantially decreased further downstream-it did not occur near or atop riffle no. 10. The large deposition of material helped widen the channel in relation to its width in 2006 (Fig. 4), especially between the dam and riffle no. 10 where the mean width of the channel increased from 16.4 to $21.7 \mathrm{~m}$ The width of the channel below riffle No. 10 virtually did not change, which serves as proof of low deposition in this river section. It may be inferred that the debris wave propagating from the dam reached riffle no. 10 covering a distance of about $1.2 \mathrm{~km}$. Channel material found further downstream came mostly from bank erosion.

The morphology and dynamics of the stream channel along the studied reaches completely changed in the years 2013-2014. Such substantial channel changes had occurred in the past due to extensive regulation works such as the construction of a dam and drop structures. The channel downstream from the dam was an erosional channel since the construction of a dam in 1951. As a result of restoration works, performed in the years 2013-2014, the channel became transformed into a depositional channel. An opposite tendency applies to the channel section between the studied dam and the footbridge-it changed from a depositional channel into an erosional one. The channel segment between the footbridge and the first drop structure changed after the erection of drop structures. Sediment trapping between drop 
Fig. 8 Deposition of material between artificial riffles: a longitudinal profile of the channel bed, $\mathbf{b}$ volume of deposited material in $\mathrm{m}^{3}$ per $1 \mathrm{~km}, \mathbf{c}$ area of bars in $\mathrm{m}^{2}$ per $1 \mathrm{~km}$

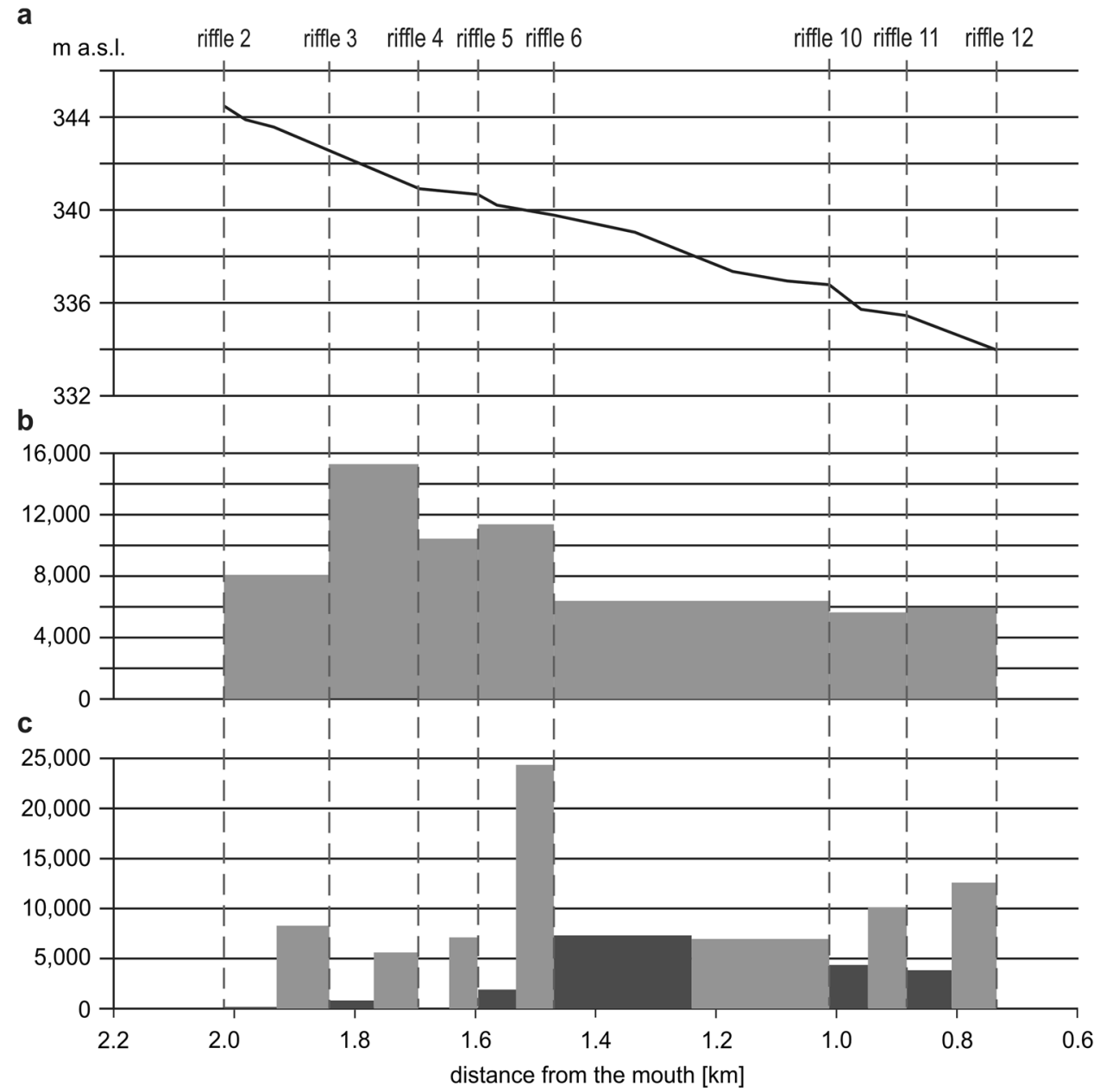

structures has been essential to its functioning as an erosional channel. Lateral erosion plays a dominant role in the shaping of the channel upstream from the dam. The threat of the loss of streambank stability, which was the original reason for the construction of the dam in the late 1990s, became relevant again. It was just within 1 year's time that lateral erosion on the left bank caused the widening of the channel by about $10 \mathrm{~m}$ along three channel sections of an approximate length of $80 \mathrm{~m}$ each. In one of such places, the river approached homes, which created a dangerous situation in the case of a flood. On the steep right bank, a landslide occurred due to a flood, which narrowed the channel and decreased its bedload capacity.

\section{Discussion}

Long-term channel changes following the lowering of a dam are due to technical interventions and also rainfall events that occur after the completion of a project (Stanley et al.
2002). This is especially the case with gravel bed streams, where the shifting of fluvial material needed to reshape the channel occurs fairly rarely-usually in the course of flood events. Such an event occurred in the Krzczonówka stream channel while the project was in progress. As a result, vast quantities of sediment became eroded out of the reservoir and then transported downstream.

The direction of stream channel change downstream from the dam was generally in agreement with the assumptions of the restoration project. Artificial riffles constructed in order to decrease the channel gradient trapped debris in the channel segments between them and prevented further transport to the Raba River. What was surprising was the extent and rate of change. It was predicted that the process of supplying material from the upper to the lower channel segment would last several years and that the channel downstream would become gradually filled with material. Meanwhile, this change occurred abruptly.

Recent studies show a two-phase process of reservoir sediment release in dam removal projects. The first phase 
of erosion occurs shortly after the lowering of the base level due to floods, both large and small, and eliminates 30-50\% of the collected debris (Major et al. 2012; Randle et al. 2015; Collins et al. 2017). The second phase depends on the size of the flood in order to activate material situated farther away from the newly formed channel. However, this erosion pattern has been proven for rivers with a sand fraction or sand fraction with some gravel. In the gravel bed Krzczonówka channel, almost all of the material was eroded in the course of a single event. Key reasons may have included small relative reservoir width (understood as the width of the reservoir relative to the width of the active river channel upstream from the reservoir). Research has shown that when a reservoir is narrow, the river may be capable of eroding the entire reservoir sediment volume over a short period of time (Morris and Fan 1997). Another example of almost complete reservoir sediment release following dam removal and a single flood event in a gravel bed mountain channel is described by Stewart (2006).

The deposition of debris in the Krzczonówka channel was the greatest just downstream of the dam, and decreased downriver, while the sediment wave stretched along a long section of stream. This appears to confirm findings by Lisle et al. (2001), Stewart (2006), Thomas et al. (2015) and Pace et al. (2017) which suggest that debris activated by floods in mountain channels, if Froude numbers are high, is transported via dispersion and not translation. In the studied channel, both pools and riffles became filled in. Wohl and Cenderelli (2000) described a case where, after a single delivery of a large amount of debris from a dam to a gravel bed channel below, the deposition covered mainly the pools. Laboratory research by Lisle et al. (2001) used a simulation of mountain river conditions to show that an abrupt delivery of debris may destroy all channel bed forms by filling in pools and riffles, as in the case of the Krzczonówka stream. Riffles buried by a sudden influx of material to the channel were also described by Egan (2001) and Kanehl et al. (1997). The time necessary for the channel to reconstruct the riffle-pool sequence and regain equilibrium after such an event is not known. It is supposed that the entire process likely takes several years in a gravel bed river, depending on the frequency of large flood events (Kanehl et al. 1997).

The reach situated between the dam and the footbridge, including the reservoir, became deepened by erosion. One year after the event, it seems that the primary role in the further development of the channel is played by lateral erosion or by landslides from the streambanks, which had lost their stability due to the deepening of the channel. The channel upstream from the dam may respond in different ways to the dam lowering, depending on local conditions, such as median grain size, level of cohesion, spatial variability of the deposit, and removal timeline (Sawaske and Freyberg 2012). According to Schumm (1993), a slight lowering of the base level does not necessarily have to lead to the deepening of a channel; a river may adjust to new conditions through a change in its pattern such as an increase in its sinuosity. However, if base level lowering is only a short-term process, such as in the case of Krzczonówka Stream, the stream most frequently responds by downcutting. The scale and rate of erosion depend on weather conditions immediately following dam lowering (Randle 2004). If a flood event occurs, vast amounts of fluvial material are set in motion immediately. Later, the rate of deepening usually decreases (Randle 2004).

Several models showing river channel adjustment to conditions associated with the dam lowering were created and tested both in the field and laboratory (e.g., Simon 1989; Simon and Hupp 1992; Doyle et al. 2002; Evans 2007; Major et al. 2012; Randle et al. 2015). According to Doyle et al. (2003), six stages in the development of a river channel above removed dams have been identified: stage A is the state of the channel that exists before dam removal, stage $\mathrm{B}$-conditions in place right after removal, but before sediment release, stage $\mathrm{C}$ - onset of downcutting, stage $\mathrm{D}$-continuation of downcutting and channel widening, stage E-further channel widening and aggradation, stage $\mathrm{F}$-emergence of a new channel equilibrium and reinforcement of an old dam reservoir with vegetation. Pizzuto (2002) states that the duration of these six stages may last several decades, while research by Stanley et al. (2002) has shown that when volume of stored sediment was small, the channel could regain its equilibrium within some months. Under the assumption that the Krzczonówka stream channel also develops in such a manner, the channel reach upstream from the dam would currently be at stage D of its development. It is worth noting that as a result of a sudden flood, stage $B$ was skipped entirely and stage $C$ occurred during one event. It is also possible that the further development of the Krzczonówka channel will not occur in line with the above model. Wildman and MacBroom (2005) have shown that in gravel bed channels with a large gradient, failure of the loose, coarse grain banks occurs with less sediment mass as in the case of cohesive banks and channel capacity exceeds the sediment supply rate, so that bed aggradation due to bank collapse is little or none. Further investigations in the Krzczonówka stream will make it possible to assess the manner and time of channel adjustment to a reduced base level.

\section{Conclusions}

The paper describes changes in the mountain Krzczonówka stream channel triggered by the lowering of a check dam and the release of large amounts of sediment. Thanks to research work on the morphology of the channel before and after 
restoration works; it was possible to document the magnitude and rate of these changes.

The observed direction of change is consistent with patterns described in the literature for river channel transitions following similar interventions. What makes the Krzczonówka case unique is the high rate of change. The acceleration of channel processes was triggered by the temporal superimposition of dam lowering work and flooding. Since the probability of the occurrence of a flood event right after the lowering of a dam is very small, the Krzczonówka case represents a valuable contribution to research on the effects of the lowering of dams.

The goals of the project of the Krzczonówka stream channel restoration were achieved. The continuity of the stream channel was restored. The stream downstream from the dam received a supply of material. The morphologic conditions in the channel became more diversified, which supports biodiversity. Fish of the Salmonidae family are now able to migrate freely to their spawning grounds. However, 1 year after the lowering of the dam, there are two problems that were not predicted earlier.

The first problem is the absence of material in the former reservoir. Almost all of the material, which was to be transported to gradually fill the stream channel segment downstream from the dam with sediment, was transported there within one night. It appears that this problem could have been partially avoided by securing reservoir sediment from too fast releasing. There exists a belief that the rate of dam lowering is relevant only in the case of large dams with large reservoirs and sediment volumes (Randle 2004). However, research in the Krzczonówka channel has shown that even in the case of small dams located on mountain streams with highly variable discharge, dam lowering most likely should occur gradually and the rate and volume of downstream sedimentation should also be controlled.

The second problem is the lack of material supply from the upstream channel section regulated using drop structures. Currently, the only source of new material is riverbanks experiencing erosion. However, it may turn out that this is insufficient and the debris shortage in Krzczonówka stream may continue in the future. Again erosion may start to dominate and the result of restoration will be lost. The problem was to be predicted by analyzing the history of regulation and evolution of the studied channel on the longer river section and over a longer period of time. This type of analysis was performed for the purpose of this paper and showed that a check dam is not the only cause for the lack of continuity of debris transport in a stream channel, which makes it impossible for fish to migrate and causes channel erosion. Drop structures are also relevant. Debris transport downstream of the structures has virtually ceased to exist since they were built. It appears that restoration cannot be fully successful without reconstruction of the continuity of the channel segment affected by drop structures. An in-depth historical analysis of a river reach intended for restoration helps to understand its functioning within the overall fluvial system, which may help in the river change planning process, forecasting of changes, and prevention of potential problems.

This research also seems to be valuable for practical reasons. There is still a large number of old, filled with sediment check dams found across the Polish Carpathian Mountains. They are important factors that reduce the ecological quality of rivers. The results of our study will help make decisions on the possible removal, lowering, reconstruction or change of purpose of selected dams.

Acknowledgements This study was financed by Poland's Ministry of Science and Higher Education. We would also like to thank Dr. Andrzej Mączałowski for his help with fieldwork

Open Access This article is distributed under the terms of the Creative Commons Attribution 4.0 International License (http://creativeco mmons.org/licenses/by/4.0/), which permits unrestricted use, distribution, and reproduction in any medium, provided you give appropriate credit to the original author(s) and the source, provide a link to the Creative Commons license, and indicate if changes were made.

\section{References}

Amos RA (2008) Upstream river responses to low head dam removal. Master's thesis, Waterloo, Canada

Bednarek AT (2001) Undamming rivers: a review of the ecological impacts of dam removal. Environ Manag 27(6):803-814

Burroughs BA, Hayes DB, Klomp KD, Hansen JF, Mistak J (2009) Effects of Stronach dam removal on fluvial geomorphology in the Pine River, Michigan, United States. Geomorphology 110:96-107

Chełmicki W, Krzemień K (1999) Channel typology for the river Feshie in the Cairngorm Mts, Scotland. In: Krzemień K (ed) River channels. Pattern, structure and dynamics. Prace Geograficzne IG UJ 104. Wyd. UJ, Cracow, pp 57-68

Collins MJ, Snyder NP, Boardman G, Banks WSL, Andrews M, Baker ME, Conlon M, Gellis A, McClain S, Miller A, Wilcock P (2017) Channel response to sediment release: insights from a paired analysis of dam removal. Earth Surf Proc Land 42:1636-1651

Doyle MW, Stanley EH, Harbor JM (2002) Geomorphic analogies for assessing probable channel response to dam removal. J Am Water Resour Assoc 38:1567-1579

Doyle MW, Stanley EH, Harbor JM (2003) Channel adjustments following two dam removals in Wisconsin. Water Resour Res 39:1011-1026

Egan J (2001) Geomorphic effects of dam removal on the Manatawny Creek. Pottstown, PA. Master's thesis, Department of Geology, University of Delaware, Newark

Evans JE (2007) Sediment impacts of the 1994 failure of IVEX dam (Chagrin River, NE Ohio): a test of channel evolution models. J Great Lakes Res 33:90-102

Gleick PH, Cooley H, Cohen MJ, Marikawa M, Morrison J, Palanappn M (2009) Dams removed or decommissioned in the United States, 1912 to present. The World's Water 2008-2009. Pacific Institute for Studies in Development, Environment, and Security, Island Press, Washington, DC 
Grant GE (2001) Dam removal: Panacea or Pandora for rivers? Invited commentary. Hydrol Process 15(8):1531-1532

Hajdukiewicz H, Wyżga B (2019) Aerial photo-based analysis of the hydromorphological changes of a mountain river over the last six decades: the Czarny Dunajec, Polish Carpathians. Sci Total Environ 648:1598-1613

Hart DD, Johnson TE, Bushaw-Newton KL, Horwitz RJ, Pizzuto JE (2004) Ecological effects of dam removal. An integrative case study and risk assessment framework for prediction. In: Graf WL (ed) Dam removal research. Status and prospects: Proceedings of the Heinz Center's dam removal research workshop, Washington, pp 67-80

Jaske RT, Goebel JB (1967) Effects of dam construction on temperatures of the Columbia River. J Am Water Works Assoc 59:935-942

Kamykowska M, Kaszowski L, Krzemień K (1999) River channel mapping instruction. Key to the river bed description. In: Krzemień K (ed), River channels. Pattern, structure and dynamics. Prace Geograficzne IG UJ 104. pp 9-25

Kanehl PD, Lyons J, Nelson JE (1997) Changes in the habitat and fish community of the Milwaukee River, Wisconsin, following removal of the Woolen Mills Dam. N Am J Fish Manag 17:387-400

Kaszowski L, Krzemień K (1977) Structure of mountain channel systems as exemplified by chosen Carpathian streams. Stud Geomorphol Carpatho-Balcanica 11:111-125

Kondolf GM, Gao Y, Annandale GW, Morris GL, Jiang E, Zhang J, Cao Y, Carling P, Fu K, Guo Q, Hotchkiss R, Peteuil C, Sumi T, Wang H-W, Wang Z, Wei Z, Wu B, Wu C, Yang CT (2014) Sustainable sediment management in reservoirs and regulated rivers: experiences from five continents. Earth's Future 2:256-280

Korpak J (2007) The influence of river training on mountain channel changes (Polish Carpathian Mountains). Geomorphology 92:166-181

Korpak J (2018) Human impact on mountains streams and rivers. In: Radecki-Pawlik A, Pagliara S, Hradecký J, Hendrickson E (eds) Open channel hydraulics, river hydraulic structures and fluvial geomorphology: for engineers, geomorphologists and physical geographers. CRC Press Taylor \& Francis Group, Boca Raton, pp 400-435

Lenar-Matyas A, Korpak J, Mączałowski A (2015) Influence of extreme discharge on restoration works in mountains river-a case study of the Krzczonówka River (southern Poland). J Ecol Eng 16(3):83-96

Liébault F, Piégay H (2001) Assessment of channel changes due to long-term bedload supply decrease, Roubion River, France. Geomorphology 36:167-186

Lisle TE, Cui Y, Parker G, Pizzuto JE, Dodd AM (2001) The dominance of dispersion in the evolution of bed material waves in gravel-bed rivers. Earth Surf Proc Land 26:1409-1420

Madej MA, Ozaki V (1996) Channel response to sediment wave propagation and movement, Redwood Creek, California, USA. Earth Surf Proc Land 21:911-927

Major JJ, O'Connor JE, Podolak CJ, Keith MK, Grant GE, Spicer KR, Pittman S, Bragg HM, Wallick JR, Tanner DQ, Rhode A, Wilcock PR (2012) Geomorphic response of the Sandy River, Oregon, to removal of Marmot Dam. US professional paper 1792, Geological Survey, Reston, Virginia

Morris GL, Fan J (1997) Reservoir sedimentation handbook, design and management of dams, reservoirs, and watersheds for sustainable use. McGraw-Hill, New York

Nachlik E (2006) Identyfikacja i ocena oddziaływań antropogenicznych na zasoby wodne zlewni Raby wraz z oszacowaniem ryzyka nieosiągnięcia celów środowiskowych. Wydawnictwo Politechniki Krakowskiej, Kraków
Pace KM, Tullos D, Walter C, Lancaster S, Segura C (2017) Sediment pulse behaviour following dam removal in gravel-bed rivers. River Res Appl 33:102-112

Park CC (1977) Man-induced changes in stream channel capacity. In: Gregory KJ (ed) River channel changes. Wiley, New York, pp 121-144

Paszkiewicz M (2009) Metodyka gospodarowania zasobami wód podziemnych z uwzględnieniem ich jakości na przykładzie zlewni Raby. Ph.D. thesis, AGH University of Science and Technology, Cracow, Poland

Petts GE, Gurnell AM (2005) Dams and geomorphology: research progress and future directions. Geomorphology 71:27-47

Pizzuto J (2002) Effects of dam removal on river form and process. Bioscience 52:683-691

Project No. 214004-00 (2011) Tarliska Górnej Raby, Opis Techniczny, Ove Arup and Partners International Ltd Sp. z o. o. Oddział w Polsce

Randle TJ (2004) Dam removal and sediment management. In: Graf WL (ed) Dam removal research. Status and prospects: Proceedings of the Heinz Center's dam removal research workshop, Washington, pp 81-104

Randle TJ, Bountry JA, Ritchie A, Wille K (2015) Large-scale dam removal on the Elwha River, Washington, USA: erosion of reservoir sediment. Geomorphology 246:709-728

Rathburn S., Wohl EE (2004) Sedimentation hazards downstream from reservoirs. In: Graf WL (ed) Dam removal research. Status and prospects: Proceedings of the Heinz Center's dam removal research workshop, Washington, pp 105-119

Ratomski J (1991) Sedymentacja rumowiska w zbiornikach przeciwrumowiskowych na obszarze Karpat fliszowych. Politechnika Krakowska, Monografia, p 123

Richards KS, Lane SN (1997) Prediction of morphological changes in unstable channels. In: Thorne CR, Hey RD, Newson MD (eds) Applied fluvial geomorphology for river engineering and management. Wiley, Chichester, pp 269-292

Sawaske SR, Freyberg DL (2012) A comparison of past small dam removals in highly sediment-impacted systems in the US. Geomorphology 151:50-58

Schumm SA (1993) River response to base level change: implications for sequence stratigraphy. J Geol 101(2):279-294

Shuman JR (1995) Environmental considerations for assessing dam removal alternatives for river restoration. Regul Rivers Res Manag 11:249-261

Simon A (1989) A model of channel response in disturbed alluvial channels. Earth Surf Process Landf 14:11-26

Simon A, Hupp CR (1992) Geomorphic and vegetative recovery process along modified stream channels of West Tennessee. Geological survey open-file report, Washington, DC, USA

Stanley EH, Doyle MW (2002) A geomorphic perspective on nutrient retention following dam removal. Bioscience 52:693-701

Stanley EH, Luebke MA, Doyle MW, Marshall DW (2002) Shortterm changes in channel form and croinvertebrate communities following low-head dam removal. J N Am Benthol Soc $21: 172-187$

Stewart G (2006) Patterns and processes of sediment transport following sediment-filled dam removal in gravel bed rivers. Ph.D. Dissertation, Oregon State University

Stewart G, Grant GE (2005) What can we learn from the removal of little dinky dams? In: Moglen G (ed) Managing watersheds for human and natural impacts. ASCE, Williamsburg

Thomas RJ, Constantine JA, Gough P, Fussell B (2015) Rapid channel widening following weir removal due to bed-material wave dispersion on the River Monnow, Wales. River Res Appl $31: 1017-1027$ 
Ward JV, Stanford JA (1995) Ecological connectivity in alluvial river ecosystems and its disruption by flow regulation. Regul Rivers Res Manag 11:105-119

Wildman LAS, MacBroom JG (2005) The evolution of gravel bed channels after dam removal: case study of the Anaconda and Union City Dam removals. Geomorphology 71:245-262

Wohl EE, Cenderelli DA (2000) Sediment deposition and transport patterns following a reservoir sediment release. Water Resour Res 36(1):319-333

Wyżga B, Radecki-Pawlik A (2011) Jak zmniejszyć zagrożenie i ryzyko powodziowe w dorzeczu górnej Wisły? Gospodarka Wodna 10:414-421
Zuchiewicz W (1998) Quaternary tectonics of the Outer West Carpathians, Poland. Tectonophysics 297:121-132

Publisher's Note Springer Nature remains neutral with regard to jurisdictional claims in published maps and institutional affiliations. 